\title{
An association between environmental factors and the IVS4+44C $>$ A polymorphism of the DMT1 gene in age-related macular degeneration
}

\author{
Daniel Wysokinski • Malgorzata Zaras • \\ Mariola Dorecka • Maja Waszczyk • Jerzy Szaflik • \\ Janusz Blasiak • Jacek P. Szaflik
}

Received: 28 September 2011 /Revised: 1 February 2012 / Accepted: 3 February 2012 / Published online: 29 February 2012

(C) The Author(s) 2012. This article is published with open access at Springerlink.com

\begin{abstract}
Background Age-related macular degeneration (AMD) is an ocular disease affecting macula - the central part of the retina, resulting in the degeneration of photoreceptors and retinal epithelium and causing severe central vision impairment. The pathophysiology of the disease is not completely known, but a significant role is attributed to genetic factors. The contribution of oxidative stress in AMD as a trigger of the degenerative process is well-established. Iron ions may act as a source of reactive oxygen species; therefore, maintaining iron homeostasis is important for redox balance in the organism. Diversity in iron homeostasis genes may counterpart in unbalanced redox state, and thus be involved in AMD pathophysiology.

Methods In this work, we searched for an association between some single nucleotide polymorphisms in the divalent metal transporter 1 (DMT1) gene intronic IVS4+44C $>$ A
\end{abstract}

The authors have full control of all primary data, and they agree to allow Graefe's Archive for Clinical and Experimental Ophthalmology to review their data upon request.

D. Wysokinski $\cdot$ J. Blasiak

Department of Molecular Genetics, University of Lodz,

Pomorska 141/143,

90-236 Lodz, Poland

M. Zaras $\cdot$ M. Waszczyk $\cdot$ J. Szaflik $\cdot$ J. P. Szaflik $(\bowtie)$

Department of Ophthalmology, Medical University of Warsaw and

Samodzielny Publiczny Kliniczny Szpital Okulistyczny,

Sierakowskiego 13,

03-709 Warsaw, Poland

e-mail: szaflik@ophthalmology.pl

M. Dorecka

Department of Ophthalmology, Medical University of Silesia,

Ceglana 35,

40-514 Katowice, Poland (rs224589) and 3'-UTR c.2044T>C (rs2285230) and environmental factors and AMD. Genotyping was performed using the PCR-RFLP method. DNA was obtained from 436 AMD patients and 168 controls.

Results We did not find any association between the genotypes of the two polymorphisms and AMD occurrence. However, we observed that AMD patients living in a rural environment and having the CC genotype of the IVS4 $+44 \mathrm{C}>\mathrm{A}$ polymorphism had an increased risk of AMD, while individuals with the CA genotype or the A allele had a decreased risk of the disease. Moreover, in male AMD patients the $\mathrm{C}$ allele increased the risk of the disease, while the AA genotype decreased it.

Conclusions These results suggest that the VS4+44C $>$ A polymorphism of the DMT1 gene may interact with place of living and gender to modulate the risk of AMD.

Keywords AMD · Age-related macular degeneration . Oxidative stress · Iron homeostasis · Gene polymorphism . Divalent metal transporter $1 \cdot$ DMT1

\section{Introduction}

Age-related macular degeneration (AMD) is the primary cause of irreversible vision loss among the elderly, in developed countries [1]. AMD is ex definitio an age-related disease, and age is its strongest risk factor. It is estimated that about $30 \%$ of individuals aged 75 or more are diagnosed with AMD [2], and this proportion is predicted to be constantly increasing due to growing live expectancy [3]. Apart from age, in some populations women are reported to be at a higher risk of AMD [4]. Caucasian ethnicity, as well as bright iris color, seems to predispose to $\operatorname{AMD}[5,6]$. 
However, the impact of sunlight exposure on AMD development has not been unambiguously established [7, 8]. Tobacco smoking is frequently reported to be an important AMD risk factor [6, 9, 10]. Cardiovascular diseases and hypertension [11], obesity [12, 13], and high-fat diet [14] are proved to enhance the risk of AMD, while the association of the disease with cataract and cataract surgery needs further research $[15,16]$.

AMD is a progressive disease, developing in its late stage to one of two clinically distinct forms - dry or wet [17]. The dry form (geographic atrophy) is characterized by drusen formation and the presence of retinal depigmentation paths as signs of the degeneration of photoreceptors together with retinal epithelium [18]. The less prevalent wet form of AMD (exudative, neovascular) is associated with a majority of total blindness incidents. The progress of the wet form of the disease is faster, with apparent choroidal neovascularization leading to leakages and bleeding into the retina $[18,19]$. A local inflammatory process appears, and a central disciform scar is formed. Photoreceptors and retinal pigment epithelium degenerate, leading to the loss of central vision [19].

The etiology of AMD is complex, and the mechanism of retinal cell death has not been fully understood. The eye is constantly exposed to short-wavelength light [20]. That causes a high rate of reactive oxygen species (ROS) generation within the eye, and this effect is augmented by high oxygen pressure in the retina [21], high rate of catabolic reactions in the inner segments of photoreceptors, and the presence of photoreactive compounds and polyunsaturated fatty acids (PUFA) in the retinal tissue [22-24]. Inflammatory processes associated with AMD may be an additional source of ROS [25].

The level of oxidative imbalance in the cell may exceed its oxidative defense capacity. Then it can cause oxidative damage to different cellular components including DNA, promoting apoptosis $[26,27]$. It is proved that iron ions may generate free radicals in vivo by Fenton reaction, and that a number of disorders developes through the iron-dependent oxidative events $[28,29]$. Severe iron overload leads to organ failure, and may cause neurodegeneration [28, 29].

Genetic factors are considered to play an important role in AMD, as has been shown in a number of family and twin studies [30]. Several genetic risk markers have been identified in this disease [23, 31]. It is thought that strong genotype-environment interaction appears in the AMD incidence [32]. In the present report, we show the interplay between the IVS4+44C $>$ A polymorphism in the DMT1 gene and environmental factors in the AMD occurrence. The DMT1 gene (also known as SLC11A2, NRAMP2) encodes transmembrane transporter of iron and other divalent ions. It plays an important role in iron uptake, and participates in keeping iron homeostasis in the organism [33].

\section{Materials and methods}

\section{Clinical subject}

This study included a group of 436 individuals - 290 with the wet form of AMD, 148 with the dry form of the disease, and 168 controls. Medical history was obtained from all subjects, and no one reported any genetic disease. The patients underwent ophthalmic examination, including best-corrected visual acuity, intraocular pressure, slit-lamp examination, and fundus examination, performed with a slit lamp equipped with either non-contact or contact fundus lenses. The criteria for enrolling patients into the study groups were based primarily on clinical usefulness; the dry form group corresponded to AREDS categories 2, 3 and 4 (geographic atrophy subtype) and the wet to AREDS category 4 (choroidal neovascularisation or neovascular maculopathy subtype) [34]. Diagnosis of AMD was confirmed by optical coherence tomography (OCT) and, in some cases, by fluorescein angiography (FA) and indocyanin green angiography (ICG). OCT evaluated retinal thickness, the presence of RPE atrophy, drusen, or subretinal fluid and intraretinal edema; angiography assessed the anatomical status of the retinal vessels, the presence of choroidal neovascularization, and leakage. The OCT examinations were performed with Stratus OCT model 3000, software version 4.0 (Oberkochen, Germany). The FA and ICG examinations were completed with a Topcon TRC-50I IX fundus camera equipped with the digital Image Net image system, version 2.14 (Topcon, Tokyo, Japan). A structured questionnaire was used to get information from study subjects about lifestyle habits and family/personal history of AMD. The genetic analyses did not interfere with diagnostic or therapeutic procedures for the subjects. The Bioethics Committee of the Medical University of Warsaw, Poland approved the study, and each patient gave written informed consent.

\section{DNA isolation}

The sample of whole venous blood was collected from every subject to EDTA-containing tubes. DNA was isolated from each sample using AxyPrep Blood Genomic DNA Miniprep kit (Axygen Biosciences, San Francisco, CA, USA) and stored deep frozen $\left(-20^{\circ} \mathrm{C}\right)$ until use.

\section{Genotyping}

\section{PCR reaction}

Each reaction tube contained $10 \mathrm{ng}$ of genomic DNA, $0.75 \mathrm{U}$ Taq Polymerase (Biotools, Madrid, Spain), $1 \times$ reaction buffer, $0.5 \mathrm{mM}$ dNTP, $1.5 \mathrm{mM} \mathrm{MgCl} \mathrm{M}_{2}$ and $0.25 \mu \mathrm{M}$ of each 
Table 1 Sequences of primers and lengths of PCR and restriction products

\begin{tabular}{|c|c|}
\hline Genotype/allele & $\begin{array}{l}\text { Primer sequences and DNA fragments after } \\
\text { digestion [bp] }\end{array}$ \\
\hline IVS4 +44 & F: 5' GACACATGCAATATCTGACATTG 3' \\
\hline$[352 \mathrm{bp}]^{\mathrm{a}}$ & R: 5' AGGCTACTATCCAACATGCAG 3' \\
\hline $\mathrm{CC}$ & $183,100,35,34$ \\
\hline $\mathrm{CA}$ & $217,183,100,35,34$ \\
\hline AA & $217,100,35$ \\
\hline Genotype/allele & $\begin{array}{l}\text { Primer sequences and DNA fragments after } \\
\text { digestion [bp] }\end{array}$ \\
\hline c. $2044 \mathrm{~T}>\mathrm{C}$ & F: 5' AAATTTCTCAGCCTTTAAAAATCC 3' \\
\hline$[231 \mathrm{bp}]^{\mathrm{a}}$ & R: 5' TTGAAAAGCTGACATTTGCTG 3' \\
\hline TT & 231 \\
\hline $\mathrm{TC}$ & $231,145,86$ \\
\hline $\mathrm{CC}$ & 145,86 \\
\hline
\end{tabular}

$\mathrm{F}$ - forward primer, $\mathrm{R}$ - reverse primer, ${ }^{\text {a) }}$ PCR product length

primer (Sigma-Aldrich, St. Louis, MO, USA). The sequence of primers for the IVS4+44C $>$ A polymorphism was as in reference [35]. The sequences of primers, and length of PCR and restriction products for both polymorphisms, are given in Table 1. PCR was run on a Bio-Rad $\mathrm{C} 1000^{\mathrm{TM}}$ thermocycler (BIO-RAD Laboratories, Hercules, CA, USA) Thermal cycling conditions for the IVS4 $+44 \mathrm{C}>\mathrm{A}$ polymorphism were: initial denaturation step at at $95^{\circ} \mathrm{C}$ for $3 \mathrm{~min}, 34$ cycles of denaturation at $95^{\circ} \mathrm{C}$ for $30 \mathrm{~s}$, annealing at $60^{\circ} \mathrm{C}$ for $30 \mathrm{~s}$ and amplification at $72^{\circ} \mathrm{C}$ for $1 \mathrm{~min}$; final extension at $72^{\circ} \mathrm{C}$ for $5 \mathrm{~min}$. For the c.2044T $>\mathrm{C}$ polymorphism, these conditions were: initial denaturation step at $95^{\circ} \mathrm{C}$ for $5 \mathrm{~min}, 33$ cycles of denaturation at $95^{\circ} \mathrm{C}$ for $30 \mathrm{~s}$, annealing at $62^{\circ} \mathrm{C}$ for $30 \mathrm{~s}$ and amplification at $72^{\circ} \mathrm{C}$ for $1 \mathrm{~min}$; final extension at $72^{\circ} \mathrm{C}$ for $5 \mathrm{~min}$.

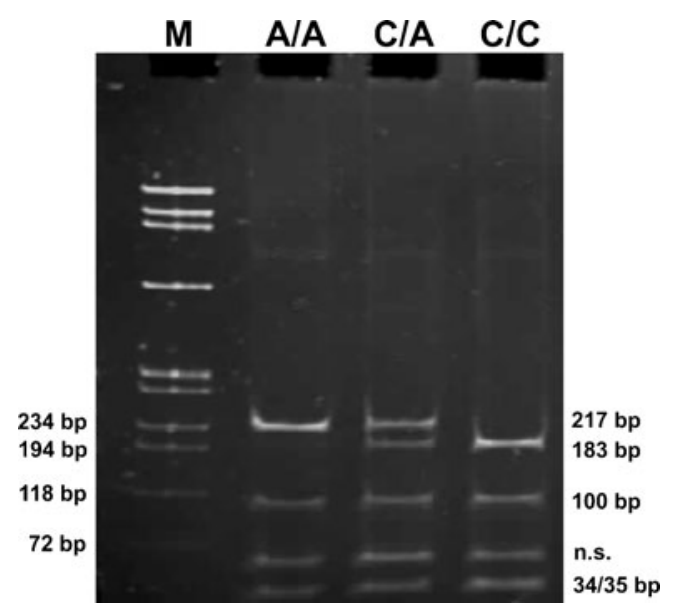

Fig. 1 The frequent gel from the IVS4+44C $>$ A polymorphism analysis. The first line $(M)$ is a DNA ladder. Two non-specific bands were visible on all gels from IVS4 $+44 \mathrm{C}>\mathrm{A}$ site analysis

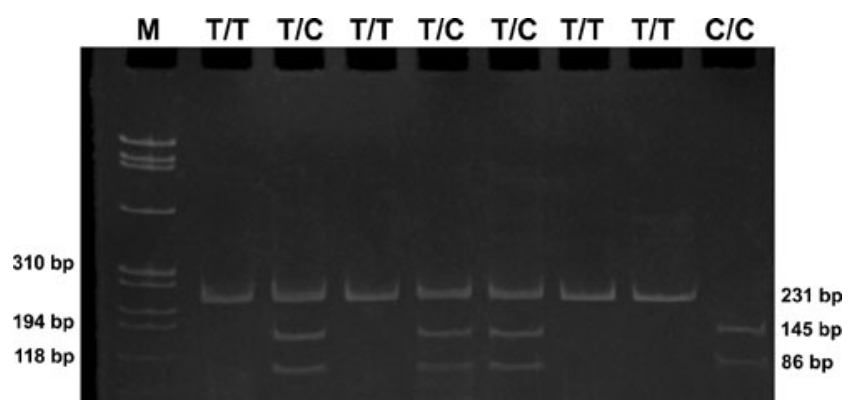

Fig. 2 The frequent gel from the c.2044T $>$ C polymorphism analysis. The first line $(M)$ is a DNA ladder

\section{Enzyme reactions}

Amplified DNA fragment containing IVS4+44C/A site was incubated with $1.5 \mathrm{U}$ of MnlI restriction enzyme (AKOR Laboratories, Gdansk, Poland) for $4 \mathrm{~h}$ at $37^{\circ} \mathrm{C}$, while fragment containing the c.2044T $>\mathrm{C}$ site was incubated with $1.5 \mathrm{U}$ of RsaI restrictase (Fermentas, Hanover, MD,USA) for $2.5 \mathrm{~h}$ in $37^{\circ} \mathrm{C}$. The length of digestion products is shown in Table 1 .

After digestion samples were separated on $10 \%$ polyacrylamide gel, electrophoresis was run at $5 \mathrm{~V} / \mathrm{cm}$ in BLUESTAR apparatus (DNA-Gdansk, Gdynia, Poland) in Trisborate-EDTA buffer. $\Phi$ X-174 DNA/BsuRI (HaeIII) DNA ladder was utilized as a mass marker. After separation, gels were stained with ethidium bromide $(0.5 \mu \mathrm{g} / \mathrm{ml})$ and documented by the digital imaging system InGenius Bio Imaging (Syngene, Cambridge, UK). Representative gels for genotyping the IVS4+44C/A and c.2044T $>$ C polymorphism are shown in Figs. 1 and 2 respectively.

Data analysis

The allelic frequencies were calculated by gene counting, and genotypes were scored. The significance of the differences between distributions of genotypes and alleles was tested using the $\chi^{2}$ analysis. Unconditional logistic regression analysis was performed to assess the association between the genotypes of the polymorphisms and AMD incidence. The genotypeassociated risk was expressed by crude odds ratio with $95 \%$

Table 2 Association of AMD with age, sex, tobacco smoking, AMD in family, BMI, and living environment

\begin{tabular}{ll}
\hline Risk Factor & OR $(95 \% \mathrm{CI})^{1}$ \\
\hline Age (for +1 year) & $1.04(1.02-1.06) ; p<0.001^{2}$ \\
Sex (for females) & $0.68(0.4-1.02)$ \\
Tobacco smoking (never vs ever) & $0.82(0.55-1.23)$ \\
AMD among 1st-degree relatives & $10.81(3.31-35.36) ; p<0.001^{2}$ \\
Body Mass Index (for +1 BMI unit) & $0.97(0.92-1.02)$ \\
Environment (for countryside) & $0.74(0.43-1.28)$ \\
\hline
\end{tabular}

${ }^{1}$ Odds ratio with $95 \%$ confidence interval, ${ }^{2}$ Chi-square test 
Table 3 Distribution of genotypes, frequency of alleles of the IVS4+44C $>$ A and c.2044T $>$ C polymorphism of the DMT1 gene, and odds ratios (OR) with $95 \%$ confidence intervals $(95 \% \mathrm{CI})$ in age-related macular degeneration and controls

\begin{tabular}{|c|c|c|c|c|}
\hline $\begin{array}{l}\text { Genotype/allele } \\
\text { IVS4+44C }>A\end{array}$ & $\begin{array}{l}\text { Control (158) } \\
N(\%)\end{array}$ & $\begin{array}{l}\text { AMD (381) } \\
N(\%)\end{array}$ & ${ }^{\mathrm{A}} \mathrm{OR}(95 \% \mathrm{CI})$ & ${ }^{\mathrm{B}} \mathrm{OR}^{\text {adjusted }}(95 \% \mathrm{CI})$ \\
\hline $\mathrm{CC}$ & $109(0.69)$ & $262(0.69)$ & $0.99(0.66-1.48)$ & $1.43(0.79-2.60)$ \\
\hline $\mathrm{CA}$ & $46(0.29)$ & $109(0.29)$ & $0.98(65-1.47)$ & $0.76(0.41-1.38)$ \\
\hline AA & $3(0.02)$ & $10(0.03)$ & $1.39(0.38-51.3)$ & $0.38(0.06-2.51)$ \\
\hline $\mathrm{C}$ & $264(0.84)$ & $633(0.83)$ & $0.97(0.68-1.38)$ & $2.63(0.40-17.43)$ \\
\hline A & $52(0.16)$ & $129(0.17)$ & $1.03(0.73-1.47)$ & $0.73(0.41-1.32)$ \\
\hline $\begin{array}{l}\text { Genotype/allele } \\
\text { c. } 2044 \mathrm{~T}>\mathrm{C}\end{array}$ & $\begin{array}{l}\text { Control (168) } \\
\text { N (\%) }\end{array}$ & $\begin{array}{l}\text { AMD (436) } \\
\text { N (\%) }\end{array}$ & ${ }^{\mathrm{A}}$ OR $(95 \% \mathrm{CI})$ & ${ }^{\mathrm{B}} \mathrm{OR}^{\text {adjusted }}(95 \% \mathrm{CI})$ \\
\hline TT & $127(0.76)$ & $320(0.73)$ & $0.86(0.59-1.34)$ & $1.23(0.65-2.35)$ \\
\hline $\mathrm{TC}$ & $39(0.23)$ & $108(0.25)$ & $1.09(0.72-1.66)$ & $0.79(0.41-1.53)$ \\
\hline $\mathrm{CC}$ & $2(0.01)$ & $8(0.02)$ & $1.55(0.33-7.38)$ & $1.75(0.19-15.86)$ \\
\hline $\mathrm{T}$ & $293(0.87)$ & $748(0.86)$ & $0.86(0.59-1.26)$ & $0.87(0.09-8.37)$ \\
\hline $\mathrm{C}$ & $41(0.12)$ & $122(0.14)$ & $1.17(0.80-1.70)$ & $0.77(0.40-1.47)$ \\
\hline
\end{tabular}

${ }^{\mathrm{A}}$ Crude odds ratio with $95 \%$ confidence interval; ${ }^{\mathrm{B}}$ Odds ratio adjusted for age, sex, and environment of living

confidence intervals and the $p$ value. Odds ratios were then adjusted for possible interfering factors. To verify a potential gene-environment interaction, the patients and controls were stratified depending on age, sex, living environment (rural or urban), smoking status and body mass index (BMI). Multiple unconditioned logistic regression analyses were run to test the association of genotypes and environmental and social factors with AMD occurrence. Statistical analysis was performed using the Statistica 9.0 package (Statsoft, Tulsa, OK, USA).

\section{Results}

The frequencies of genotypes in the groups did not differ significantly from Hardy-Weinberg equilibrium $-p>0.05$ for each group. The patient characteristics contained information about environmental and social factors having possible impact on AMD incidence. The analysis of the association between potential risk factors - age, sex, inhabitation, smoking habit, and Body Mass Index and AMD independently from genotypes was performed (Table 2). We found no association of sex, environment, BMI, and tobacco smoking with AMD. We observed a significant association of AMD with age (OR 1.04; 95\% CI 1.02-1.06; $p<0.001$; for every additional year) and the occurrence of the disease among 1st-degree relatives (OR 10.81; 95\% CI 3.31-35.36; $p<0.001)$. The next step was to test the association between the genotypes of both polymorphisms and AMD. No association was found between the risk of AMD and the genotypes of that polymorphism in the group of all AMD
Table 4 Distribution of genotypes, frequency of alleles of the IVS4 $+44 \mathrm{C}>\mathrm{A}$ and c. $2044 \mathrm{~T}>\mathrm{C}$ polymorphism of the DMT1 gene, and odds ratios (OR) with $95 \%$ confidence intervals $(95 \%$ $\mathrm{CI}$ ) in wet form of age-related macular degeneration and controls

\begin{tabular}{|c|c|c|c|c|}
\hline $\begin{array}{l}\text { Genotype/allele } \\
\text { IVS4+44C }>A\end{array}$ & $\begin{array}{l}\text { Control (158) } \\
N(\%)\end{array}$ & $\begin{array}{l}\text { Wet AMD (233) } \\
N(\%)\end{array}$ & ${ }^{\mathrm{A}} \mathrm{OR}(95 \% \mathrm{CI})$ & ${ }^{\mathrm{B}} \mathrm{OR}^{\text {adjusted }}(95 \% \mathrm{CI})$ \\
\hline $\mathrm{CC}$ & $109(0.69)$ & $163(0.70)$ & $1.13(0.72-1.76)$ & $1.57(0.79-3.12)$ \\
\hline CA & $46(0.29)$ & $65(0.28)$ & $0.94(0.60-1.47)$ & $0.73(0.37-1.45)$ \\
\hline AA & $3(0.02)$ & $5(0.02)$ & $0.66(0.16-2.80)$ & $0.16(0.01-1.95)$ \\
\hline $\mathrm{C}$ & $264(0.84)$ & $391(0.84)$ & $1.03(0.70-1.51)$ & $6.29(0.51-77.15)$ \\
\hline A & $52(0.16)$ & $75(0.16)$ & $0.97(0.66-1.43)$ & $0.69(0.35-1.36)$ \\
\hline $\begin{array}{l}\text { Genotype/allele } \\
\text { c. } 2044 \mathrm{~T}>\mathrm{C}\end{array}$ & $\begin{array}{l}\text { Control (168) } \\
N(\%)\end{array}$ & $\begin{array}{l}\text { Wet AMD (290) } \\
N(\%)\end{array}$ & ${ }^{\mathrm{A}} \mathrm{OR}(95 \% \mathrm{CI})$ & ${ }^{\mathrm{B}} \mathrm{OR}^{\text {adjusted }}(95 \% \mathrm{CI})$ \\
\hline TT & $127(0.76)$ & $217(0.75)$ & $0.96(0.62-1.49)$ & $1.30(0.62-2.70)$ \\
\hline $\mathrm{TC}$ & $39(0.23)$ & $70(0.24)$ & $1.05(0.67-1.65)$ & $0.82(0.39-1.71)$ \\
\hline $\mathrm{CC}$ & $2(0.01)$ & $3(0.01)$ & $0.87(0.14-5.25)$ & $1.23(0.10-15.21)$ \\
\hline $\mathrm{T}$ & $293(0.87)$ & $504(0.87)$ & $0.93(0.62-1.39)$ & $2.62(0.15-45.54)$ \\
\hline $\mathrm{C}$ & $41(0.12)$ & $76(0.13)$ & $1.08(0.72-1.62)$ & $0.70(0.33-1.47)$ \\
\hline
\end{tabular}


Table 5 Distribution of genotypes, frequency of alleles of the IVS4+44C $>$ A and c.2044T $>C$ polymorphism of the $D M T 1$ gene, and odds ratios (OR) with $95 \%$ confidence intervals $(95 \%$ CI) in dry form of age-related macular degeneration and controls

\begin{tabular}{|c|c|c|c|c|}
\hline $\begin{array}{l}\text { Genotype/allele } \\
\text { IVS4+44C }>A\end{array}$ & $\begin{array}{l}\text { Control (158) } \\
N(\%)\end{array}$ & $\begin{array}{l}\text { Dry AMD (148) } \\
N(\%)\end{array}$ & ${ }^{\mathrm{A}} \mathrm{OR}(95 \% \mathrm{CI})$ & ${ }^{\mathrm{B}} \mathrm{OR}^{\text {adjusted }}(95 \% \mathrm{CI})$ \\
\hline $\mathrm{CC}$ & $109(0.69)$ & $99(0.67)$ & $0.91(0.56-1.47)$ & $1.27(0.62-2.60)$ \\
\hline $\mathrm{CA}$ & $46(0.29)$ & $44(0.30)$ & $1.03(0.63-1.68)$ & $0.82(0.40-1.69)$ \\
\hline AA & $3(0.02)$ & $5(0.03)$ & $1.81(0.42-7.70)$ & $0.65(0.08-5.19)$ \\
\hline $\mathrm{C}$ & $264(0.84)$ & $242(0.82)$ & $0.88(0.58-1.34)$ & $1.54(0.19-12.28)$ \\
\hline A & $52(0.16)$ & $54(0.18)$ & $1.13(0.75-1.72)$ & $0.79(0.38-1.61)$ \\
\hline $\begin{array}{l}\text { Genotype/allele } \\
\text { c. } 2044 \mathrm{~T}>\mathrm{C}\end{array}$ & $\begin{array}{l}\text { Control (168) } \\
N(\%)\end{array}$ & $\begin{array}{l}\text { Dry AMD (146) } \\
N(\%)\end{array}$ & ${ }^{\mathrm{A}} \mathrm{OR}(95 \% \mathrm{CI})$ & ${ }^{\mathrm{B}} \mathrm{OR}^{\text {adjusted }}(95 \% \mathrm{CI})$ \\
\hline TT & $127(0.76)$ & $103(0.71)$ & $0.77(0.47-1.28)$ & $1.14(0.53-2.48)$ \\
\hline $\mathrm{TC}$ & $39(0.23)$ & $38(0.26)$ & $1.16(0.70-1.95)$ & $0.78(0.35-1.73)$ \\
\hline $\mathrm{CC}$ & $2(0.01)$ & $5(0.03)$ & $2.94(0.56-15.40)$ & $2.31(0.22-24.03)$ \\
\hline $\mathrm{T}$ & $293(0.87)$ & $244(0.84)$ & $0.71(0.45-1.12)$ & $0.43(0.04-4.52)$ \\
\hline $\mathrm{C}$ & $41(0.12)$ & $48(0.16)$ & $1.41(0.90-2.21)$ & $0.88(0.40-1.90)$ \\
\hline
\end{tabular}

\section{Discussion}

Age-related macular degeneration is an important health problem in developed countries. A constantly growing percentage of affected individuals and the estimated tendency that it will rise over the next years is an argument confirming the urgency of revealing the nature of AMD. That includes searching for genetic markers of this disease, since it is established that AMD have features of inherited disease [30-32]. Several genetic polymorphisms significantly affecting AMD has been identified. These include polymorphisms in the CFH, CFB, C2, ERCC6, HTRA, VEGF and other genes [36]. In the present study, we analyzed polymorphisms in the divalent metal transporter 1 (DMT1) gene and their association with AMD risk. Iron homeostasis is crucial for proper functioning of the organism, and while iron deficiency leads to anemia, its excess may cause severe symptoms. In a number of cases, iron overload leads to heart, liver or brain damage [37, 38]. It is particularly visible in hereditary haemochromatosis - genetic defects in one of the iron homeostasis genes, associated with iron accumulation in the organism [39]. Moreover, the elevated iron level
Table 6 Distribution of combined genotypes of the IVS4 $+44 \mathrm{C}>\mathrm{A}$ and c. $2044 \mathrm{~T}>\mathrm{C}$ polymorphism of the DMT1 gene and odds ratios (OR) with $95 \%$ confidence intervals $(95 \% \mathrm{CI})$ in age-related macular degeneration and controls

A Crude odds ratio with $95 \%$
confidence interval; ${ }^{\text {B Odds ratio }}$
adjusted for age. sex and envi-
ronment of living

\begin{tabular}{|c|c|c|c|c|}
\hline $\begin{array}{l}\text { Genotype } \\
\text { IVS4+44C }>\text { A /c. } 2044 T>C\end{array}$ & $\begin{array}{l}\text { Control (158) } \\
N(\%)\end{array}$ & $\begin{array}{l}\mathrm{AMD}(377) \\
N(\%)\end{array}$ & ${ }^{\mathrm{A}} \mathrm{OR}(95 \% \mathrm{CI})$ & ${ }^{\mathrm{B}} \mathrm{OR}^{\text {adjusted }}(95 \% \mathrm{CI})$ \\
\hline $\mathrm{CC} / \mathrm{TT}$ & $107(0.68)$ & $249(0.66)$ & $0.93(0.62-1.38)$ & $1.33(0.74-2.38)$ \\
\hline $\mathrm{CC} / \mathrm{TC}$ & $2(0.01)$ & $8(0.02)$ & $1.69(0.36-8.05)$ & $2.19(0.19-25.36)$ \\
\hline $\mathrm{CC} / \mathrm{CC}$ & $0(0)$ & $1(0)$ & - & - \\
\hline $\mathrm{CA} / \mathrm{TT}$ & $12(0.08)$ & $25(0.07)$ & $0.86(0.42-1.77)$ & $0.73(0.28-1.96)$ \\
\hline $\mathrm{CA} / \mathrm{TC}$ & $34(0.22)$ & $84(0.22)$ & $1.05(0.67-1.64)$ & $0.81(0.41-1.59)$ \\
\hline $\mathrm{CA} / \mathrm{CC}$ & $0(0)$ & $0(0)$ & - & - \\
\hline $\mathrm{AA} / \mathrm{TT}$ & $0(0)$ & $0(0)$ & - & - \\
\hline $\mathrm{AA} / \mathrm{TC}$ & $1(0.01)$ & $4(0.01)$ & $1.68(0.19-15.18)$ & - \\
\hline $\mathrm{AA} / \mathrm{CC}$ & $2(0.01)$ & $6(0.02)$ & $1.26(0.25-6.32)$ & $0.91(0.09-9.32)$ \\
\hline
\end{tabular}


Table 7 Distribution of genotypes. frequency of alleles of the IVS4+44C $>$ A and c.2044T $>$ C polymorphism of the DMT1 gene, and odds ratios $(\mathrm{OR})$ with $95 \%$ confidence intervals $(95 \% \mathrm{CI})$ in age-related macular degeneration and controls among urban and countryside ancestors

\begin{tabular}{|c|c|c|c|c|c|c|}
\hline \multirow[b]{2}{*}{$\begin{array}{l}\text { Genotype/allele } \\
\text { IVS4+44C }>\text { A }\end{array}$} & \multicolumn{3}{|l|}{ Urban district } & \multicolumn{3}{|l|}{ Countryside } \\
\hline & $\begin{array}{l}\text { Control (55) } \\
N(\%)\end{array}$ & $\begin{array}{l}\text { Dry AMD (113) } \\
N(\%)\end{array}$ & ${ }^{\mathrm{A}} \mathrm{OR}(95 \% \mathrm{CI})$ & $\begin{array}{l}\text { Control (33) } \\
N(\%)\end{array}$ & $\begin{array}{l}\text { Dry AMD (50) } \\
N(\%)\end{array}$ & ${ }^{\mathrm{A}} \mathrm{OR}(95 \% \mathrm{CI})$ \\
\hline $\mathrm{CC}$ & $40(0.73)$ & $77(0.68)$ & $0.94(0.45-1.99)$ & $20(0.61)$ & $40(0.80)$ & $3.50(1.19-10.31) *$ \\
\hline $\mathrm{CA}$ & $13(0.24)$ & $33(0.29)$ & $1.24(0.58-2.68)$ & $13(0.39)$ & $10(0.20)$ & $0.29(0.10-0.84) *$ \\
\hline AA & $2(0.04)$ & $3(0.03)$ & $0.31(0.04-2.18)$ & $0(0)$ & $0(0)$ & - \\
\hline $\mathrm{C}$ & $93(0.85)$ & $187(0.83)$ & $3.25(0.46-23.04)$ & $53(0.80)$ & $90(0.90)$ & - \\
\hline A & $17(0.15)$ & $39(0.17)$ & $1.14(0.54-2.39)$ & $13(0.20)$ & $10(0.10)$ & $0.29(0.10-0.84) *$ \\
\hline $\begin{array}{l}\text { Genotype/allele } \\
\text { c. } 2044 \mathrm{~T}>\mathrm{C}\end{array}$ & $\begin{array}{l}\text { Control (56) } \\
N(\%)\end{array}$ & $\begin{array}{l}\text { Dry AMD (113) } \\
N(\%)\end{array}$ & ${ }^{\mathrm{A}} \mathrm{OR}(95 \% \mathrm{CI})$ & $\begin{array}{l}\text { Control (33) } \\
N(\%)\end{array}$ & $\begin{array}{l}\text { Dry AMD (50) } \\
N(\%)\end{array}$ & ${ }^{\mathrm{A}} \mathrm{OR}(95 \% \mathrm{CI})$ \\
\hline TT & $45(0.80)$ & $82(0.73)$ & $0.789(0.35-1.78)$ & $23(0.70)$ & $42(0.84)$ & $3.03(0.94-9.76)$ \\
\hline $\mathrm{TC}$ & $10(0.18)$ & $27(0.24)$ & $1.29(0.56-3.00)$ & $10(0.30)$ & $7(0.14)$ & $0.33(0.10-1.07)$ \\
\hline $\mathrm{CC}$ & $1(0.02)$ & $4(0.03)$ & $0.97(0.10-9.77)$ & $0(0)$ & $1(0.02)$ & - \\
\hline $\mathrm{T}$ & $100(0.89)$ & $191(0.85)$ & $1.03(0.10-10.30)$ & $56(0.85)$ & $91(0.91)$ & - \\
\hline $\mathrm{C}$ & $12(0.11)$ & $35(0.15)$ & $1.19(0.52-2.69)$ & $10(0.15)$ & $9(0.09)$ & $0.33(0.10-1.07)$ \\
\hline
\end{tabular}

A Odds ratio adjusted for age and sex; $* p<0.05$

may stimulate cancer transformation [40]. Many age-related diseases may be connected with an elevated iron level associated with aging [41, 42]. The mechanism of ironrelated harmful effects in the organism involves the action of free radicals. Free divalent iron ions participate in the Fenton reaction, producing highly reactive hydroxyl radicals, which may damage cellular components, including DNA, and impair DNA repair [43]. An elevated level of chelatable iron ions has been observed in maculas derived post mortem from AMD patients [44]. Mice lacking key genes of iron homeostasis - ceruloplasmin, hephaestin and hepcidin - developed retinal degeneration with features of AMD [45, 46]. Similarly, the case of a patient with a defect in the ceruloplasmin gene has been reported. The patient suffered from AMD, and an increased iron content in the macula of the patient was shown [47]. It was also shown, in a mouse model of AMD and RPE cell line, that iron chelation protected from AMD development [45, 48].

Table 8 Distribution of genotypes. frequency of alleles of the IVS4+44C $>$ A and c.2044T $>$ C polymorphism of the DMT1 gene, and odds ratios (OR) with $95 \%$ confidence intervals $(95 \% \mathrm{CI})$ in age-related macular degeneration and controls among males and females

\begin{tabular}{|c|c|c|c|c|c|c|}
\hline \multirow[b]{2}{*}{$\begin{array}{l}\text { Genotype/allele } \\
\text { IVS4+44C }>\text { A }\end{array}$} & \multicolumn{3}{|l|}{ Males } & \multicolumn{3}{|l|}{ Females } \\
\hline & $\begin{array}{l}\text { Control (39) } \\
N(\%)\end{array}$ & $\begin{array}{l}\text { Dry AMD (127) } \\
N(\%)\end{array}$ & ${ }^{\mathrm{A}} \mathrm{OR}(95 \% \mathrm{CI})$ & $\begin{array}{l}\text { Control (119) } \\
N(\%)\end{array}$ & $\begin{array}{l}\text { Dry AMD (254) } \\
N(\%)\end{array}$ & ${ }^{\mathrm{A}} \mathrm{OR}(95 \% \mathrm{CI})$ \\
\hline $\mathrm{CC}$ & $27(0.69)$ & $78(0.61)$ & $1.49(0.49-4.57)$ & $82(0.69)$ & $184(0.72)$ & $1.44(0.71-2.93)$ \\
\hline $\mathrm{CA}$ & $10(0.26)$ & $44(0.35)$ & $1.09(0.34-3.47)$ & $36(0.30)$ & $65(0.26)$ & $0.66(0.32-1.35)$ \\
\hline AA & $2(0.05)$ & $5(0.04)$ & $0.11(0.01-.98) *$ & $1(0.01)$ & $5(0.02)$ & - \\
\hline $\mathrm{C}$ & $64(0.82)$ & $200(0.79)$ & $9.56(1.02-9.99) *$ & $200(0.85)$ & $433(0.85)$ & - \\
\hline A & $14(0.18)$ & $54(0.21)$ & $0.67(0.22-2.05)$ & $38(0.16)$ & $75(0.15)$ & $0.75(0.37-1.51)$ \\
\hline $\begin{array}{l}\text { Genotype/allele } \\
\text { c. } 2044 \mathrm{~T}>\mathrm{C}\end{array}$ & $\begin{array}{l}\text { Control (43) } \\
N(\%)\end{array}$ & $\begin{array}{l}\text { Dry AMD (129) } \\
N(\%)\end{array}$ & ${ }^{\mathrm{A}} \mathrm{OR}(95 \% \mathrm{CI})$ & $\begin{array}{l}\text { Control (125) } \\
N(\%)\end{array}$ & $\begin{array}{l}\text { Dry AMD (306) } \\
N(\%)\end{array}$ & ${ }^{\mathrm{A}} \mathrm{OR}(95 \% \mathrm{CI})$ \\
\hline TT & $32(0.74)$ & $87(0.67)$ & $2.00(0.60-6.66)$ & $95(0.76)$ & $232(0.76)$ & $1.04(0.48-2.27)$ \\
\hline $\mathrm{TC}$ & $10(0.23)$ & $37(0.29)$ & $0.57(0.17-1.94)$ & $29(0.23)$ & $71(0.23)$ & $0.91(0.42-1.99)$ \\
\hline $\mathrm{CC}$ & $1(0.03)$ & $590.04)$ & $0.45(0.04-5.13)$ & $1(0.01)$ & $3(0.01)$ & - \\
\hline $\mathrm{T}$ & $74(0.86)$ & $211(0.82)$ & $2.24(0.20-25.72)$ & $219(0.88)$ & $535(0.87)$ & - \\
\hline $\mathrm{C}$ & $12(0.14)$ & $47(0.18)$ & $0.47(0.14-1.58)$ & $31(0.12)$ & $77(0.13)$ & $0.92(0.42-2.02)$ \\
\hline
\end{tabular}

A Odds ratio adjusted for age and living environment; * $\mathrm{p}<0.05$ 
In this paper, we have analyzed two SNP polymorphisms in the DMT1 gene. This gene has two alternative promoters and two alternative polyadenylation sites. Four main isoforms of DMT1 have been identified. Depending on the choice of polyadenylation site, the transcript may include the iron response element (IRE) in the 3'UTR region [49, 50]. The differences between isoforms determine mainly the tissue-specific expression pattern of the final protein [51]. DMT1 plays a role in iron absorption from the intestine and its endosomal transport in the cell, being responsible for cellular distribution of this metal $[52,53]$. DMT1 also plays an important role in cation balance in the nervous system $[52,53]$. There are reports concerning imbalance of iron in the organism as a consequence of mutations in the DMT1 gene $[54,55]$. It has also been postulated that DMT1 plays a role in the process of neurodegeneration [56]. The IVS4 $+44 \mathrm{C}>\mathrm{A}$ polymorphism is located in the intron 4 of the DMT1 gene. A nucleotide change inside the intron may affect significantly either constitutive splicing or alternative splicing by the corruption of splicing regulatory cis-elements, giving incorrect isoforms of the protein [57, 58]. This polymorphism has been reported not to be associated with inflammatory bowel disease [59] and hereditary haemochromatosis [60], but its association with Parkinson's disease has been shown [35]. We did not find any report on the functional significance of the other polymorphism, c. 2044T $>$ C.

Our genotype-independent analysis of potential AMD risk factors showed an association with age and a strong association with familial AMD. Therefore, positive AMD familial history may increase the risk of the occurrence of the disease among remaining family members. On the other hand, we found no association of AMD with smoking status, sex, BMI, and place of living. In particular, the lack of association of AMD with sex and smoking is somehow surprising, because several groups have shown a significant association between tobacco smoking and AMD [61]. Furthermore, female sex was reported as an AMD risk factor in several populations [4]. We do not have information on the general association between AMD occurrence and gender in Poland, so we can conclude that the dependence of the AMD risk on sex may be population-specific, or that our studies lacked power to detect this dependence, and further investigations in the Polish population are needed to clarify this point. Tobacco smoking is well-confirmed as a modulator of AMD risk, although some groups have reported no association between smoking and AMD, or only a limited, borderline association [62-65]. Again, the dependence between smoking and AMD may be population-specific and influenced by passive smoking, which should not be ignored [66]. Stratification of patients depending on age, sex, BMI, living environment and tobacco smoking status revealed no correlation between these factors, AMD, and the genotypes of the c.2044T $>$ C polymorphism. However, in the group of rural inhabitants, the polymorphism IVS4+44C $>$ A was significantly correlated with AMD risk. The $\mathrm{C}$ variant seemed to increase the AMD risk if it occurred among rural inhabitants, while the A variant had a protective role. Similarly, the $\mathrm{C}$ variant strongly positively increased AMD risk among males, and the A variant decreased the risk in this group. This is particularly interesting, since in a number of researches in other populations, females were at higher risk of AMD [4]. No significant influence of a tobacco smoking habit is also worth emphasizing, as tobacco smoking is thought to be a major risk factor in AMD. Our result showed that the IVS4+44C $>$ A polymorphism in DMT1 gene may be considered as a potential environment-dependent risk marker for AMD.

Acknowledgements This work was supported by grant N N402 248 336 from Polish Ministry of Science and Higher Education.

Open Access This article is distributed under the terms of the Creative Commons Attribution License which permits any use, distribution, and reproduction in any medium, provided the original author(s) and the source are credited.

\section{References}

1. Prevent Blindness America (2002) Vision problems in the U.S.: prevalence of adult vision impairment and age-related eye disease in America. Prevent Blindness America, Schaumburg IL, pp 1-21

2. Tomany SC, Wang JJ, Van Leeuwen R, Klein R, Mitchell P, Vingerling JR, Klein BE, Smith W, De Jong PT (2004) Risk factors for incident age-related macular degeneration: pooled findings from 3 continents. Ophthalmology 11:1280-1287

3. Klein R, Klein BE, Knudtson MD, Meuer SM, Swift M, Gangnon RE (2007) Fifteen-year cumulative incidence of age-related macular degeneration: the Beaver Dam Eye Study. Ophthalmology 114:253-262

4. Busch H, Vinding T, la Cour M, Jensen GB, Prause JU, Nielsen NV (2005) Risk factors for age-related maculopathy in 14-year follow-up study: the Copenhagen City Eye Study. Acta Ophthalmol Scand 83:409-418

5. Frank RN, Puklin JE, Stock C, Canter LA (2000) Race, iris color, and age-related macular degeneration. Trans Am Ophthalmol Soc 98:109-117

6. Liutkeviciene R, Lesauskaite V, Asmoniene V, Zaliuniene D, Jasinskas V (2010) Factors determining age-related macular degeneration: a current view. Medicina 46:89-94

7. West SK, Rosenthal FS, Bressler NM, Bressler SB, MunozB FSL (1989) Exposure to sunlight and other risk factors for age-related macular degeneration. Arch Ophthalmol 107:875-879

8. Tomany SC, Cruickshanks KJ, Klein R, Klein BE, Knudtson MD (2004) Sunlight and the 10-year incidence of age-related maculopathy: the Beaver Dam Eye Study. Arch Ophthalmol 122:750-757

9. Thornton J, Edwards R, Mitchell P, Harrison RA, Buchan I, Kelly SP (2005) Smoking and age-related macular degeneration: review of association. Eye 19:935-944

10. Chakravarthy U, Augood C, Bentham GC, de Jong PT, Rahu M, Seland J, Soubrane G, Tomazzoli L, Topouzis F, Vingerling JR, Viogue J, Young IS, Fletcher AE (2007) Cigarette smoking and age-related macular degeneration in the EUREYE study. Ophthalmology 114:1157-1163 
11. Hogg RE, Woodside JV, Gilchrist SE, Graydon R, Fletcher AE, Chan W, Knox A, Cartmill B, Chakravarthy U (2008) Cardiovascular disease and hypertension are strong risk factors for choroidal neovascularization. Ophthalmology 115:1046-1052

12. Clemons TE, Milton RC, Klein R, Seddon JM, Ferris FL (2005) Risk factors for the incidence of advanced age-related macular degeneration in the Age-Related Eye Disease Study (AREDS): AREDS report No. 19. Ophthalmology 112:533-539

13. Peeters A, Magliano DJ, Stevens J, Duncan BB, Klein R, Wong TY (2008) Changes in abdominal obesity and age-related macular degeneration. Arch Ophthalmol 126:1554-1560

14. SanGiovanni JP, Chew EY, Clemons TE, Davis MD, Ferris FL 3rd, Gensler GR, Kurinij N, Lindblad AS, Milton RC, Seddon JM, Sperduto RD, Age-Related Eye Disease Study Research Group (2007) The relationship of dietary lipid intake and age-related macular degeneration in a case-control study: AREDS Report No. 20. Arch Ophthalmol 125:671-679

15. Ho L, Boekhoorn SS, Liana, van Duijn CM, Uitterlinden AG, Hofman A, de Jong PT, Stijnen T, Vingerling JR (2008) Cataract surgery and the risk of aging macula disorder: The Rotterdam Study. Invest Ophthalmol Vis Sci 49:4795-4800

16. Klein BE, Klein R, Lee KE (1998) Incidence of age-related cataract: the Beaver Dam Eye Study. Arch Ophthalmol 116:219-225

17. Hamdi HK, Kenney C (2003) Age-related macular degeneration: a new viewpoint. Front Biosci 8:e305-e314

18. Coleman HR, Chan CC, Ferris FL 3rd, Chew EY (2008) Agerelated macular degeneration. Lancet 372:1835-1845

19. Bressler SB (2009) Introduction: Understanding the role of angiogenesis and antiangiogenic agents in age-related macular degeneration. Ophthalmology 116(10 suppl):S1-S7

20. Sliney DH (2002) How light reaches the eye and its components. Int J Toxicol 21:501-509

21. Roth F, Bindewald A, Holz FG (2004) Key pathologic pathways in age-related macular disease. Graefes Arch Clin Exp Ophthalmol 242:710-716

22. Chalam KV, Khetpal V, Rusovici R, Balaiya S (2011) A review: role of ultraviolet radiation in age-related macular degeneration. Eye Contact Lens 37:225-232

23. Ding X, Patel M, Chan CC (2009) Molecular pathology of agerelated macular degeneration. Prog Retin Eye Res 28:1-18

24. Murdaugh LS, Avalle LB, Mandal S, Dill AE, Dillon J, Simon JD, Gaillard ER (2010) Compositional studies of human RPE lipofuscin. J Mass Spectrom 45:1139-1147

25. Lau L, Chiou SH, Liu CJ, Yen MY, Wei YH (2011) The effect of photo-oxidative stress and inflammatory cytokine on complement factor $\mathrm{H}$ expression in retinal pigment epithelial cells. Invest Ophthalmol Vis Sci 52:6832-6841

26. Kasahara E, Lin LR, Ho YS, Reddy VN (2005) SOD2 protects against oxidation-induced apoptosis in mouse retinal pigment epithelium: implications for age-related macular degeneration. Invest Ophthalmol Vis Sci 46:3426-3434

27. Justilien V, Pang JJ, Renganathan K, Zhan X, Crabb JW, Kim SR, Sparrow JR, Hauswirth WW, Lewin AS (2007) SOD2 knockdown mouse model of early AMD. Invest Ophthalmol Vis Sci 48:4407-4420

28. Pietrangelo A (2010) Hereditary hemochromatosis: pathogenesis, diagnosis, and treatment. Gastroenterology 139:393-408

29. Brissot P, Bardou-Jacquet E, Troadec MB, Mosser A, Island ML, Detivaud L, Loreal O, Jouanolle AM (2010) Molecular diagnosis of genetic iron-overload disorders. Expert Rev Mol Diagn 10:755-763

30. Hammond CJ, Webster AR, Snieder H, Bird AC, Gilbert CE, Spector TD (2002) Genetic influence on early age-related maculopathy: a twin study. Ophthalmology 109:730-736

31. Montezuma SR, Sobrin L, Seddon JM (2007) Review of genetics in age related macular degeneration. Semin Ophthalmol 22:229-240

32. Chen Y, Bedell M, Zhang K (2010) Age-related macular degeneration: genetic and environmental factors of disease. Mol Interv 10:271-281
33. Wang D, Song Y, Li J, Wang C, Li F (2011) Structure and metal ion binding of the first transmembrane domain of DMT1. Biochim Biophys Acta 1808:1639-1644

34. Age-Related Eye Disease Study Group (2000) Risk factors associated with age-related macular degeneration. A case-control study in the age-related eye disease study: Age-Related Eye Disease Study Report Number 3. Ophthalmology 107:2224-2232

35. Kayaalti Z, Odabasi M, Soylemezoglu T (2011) Genotype and allele frequencies of divalent metal transporter 1 polymorphism in Turkish population. Mol Biol Rep 38:2679-2684

36. Ross JR, Verma V, Rosenberg IK, Chan CC, Tuo J (2007) Genetic markers and biomarkers for age-related macular degeneration. Expert Rev Ophthalmol 2:443-457

37. Weinberg ED (2010) The hazards of iron loading. Metallomics 2:732-740

38. Shander A, Cappellini MD, Goodnough LT (2009) Iron overload and toxicity: the hidden risk of multiple blood transfusions. Vox Sang 97:185-197

39. Camaschella C, Poggiali E (2011) Inherited disorders of iron metabolism. Curr Opin Pediatr 23:14-20

40. Steegmann-Olmedillas JL (2011) The role of iron in tumor cell proliferation. Clin Transl Oncol 13:71-76

41. Brewer GJ (2010) Risk of copper and iron toxicity during aging in humans. Chem Res Toxicol 23:319-326

42. Xu J, Marzetti E, Seo AY, Kim JS, Prolla TA, Leeuwenburgh C (2010) The emerging role of iron dyshomeostasis in the mitochondrial decay of aging. Mech Ageing Dev 131:487-493

43. Jomova K, Valko M (2011) Advances in metal-induced oxidative stress and human disease. Toxicology 283:65-87

44. Hahn P, Milam AH, Dunaief JL (2003) Maculas affected by agerelated macular degeneration contain increased chelatable iron in the retinal pigment epithelium and Bruch's membrane. Arch Ophthalmol 121:1099-1105

45. Hadziahmetovic M, Song Y, Ponnuru P, Iacovelli J, Hunter A, Haddad N, Beard J, Connor JR, Vaulont S, Dunaief JL (2011) Age-dependent retinal iron accumulation and degeneration in hepcidin knockout mice. Invest Ophthalmol Vis Sci 52:109-118

46. Hadziahmetovic M, Song Y, Wolkow N, Iacovelli J, Grieco S, Lee J, Lyubarsky A, Pratico D, Connelly J, Spino M, Harris ZL, Dunaief JL (2011) The oral iron chelator deferiprone protects iron overload-induced retinal degeneration. Invest Ophthalmol Vis Sci 52:959-968

47. Dunaief JL, Richa C, Franks EP, Schultze RL, Aleman TS, Schenck JF, Zimmerman EA, Brooks DG (2005) Macular degeneration in a patient with aceruloplasminemia, a disease associated with retinal iron overload. Ophthalmology 112:1062-1065

48. Lukinova N, Iacovelli J, Dentchev T, Wolkow N, Hunter A, Amado D, Ying GS, Sparrow JR, Dunaief JL (2009) Iron chelation protects the retinal pigment epithelial cell line ARPE-19 against cell death triggered by diverse stimuli. Invest Ophthalmol Vis Sci 50:1440-1447

49. Garrick DM, Garrick ML (2009) Cellular iron transporters. Biochim Biophys Acta 1790:309-325

50. Garrick DM (2011) Human iron transporters. Genes Nutr 6:45-54

51. Mackenzie B, Takanaga H, Hubert N, Rolfs A, Hediger MA (2007) Functional properties of multiple isoforms of human divalent metal-ion transporter 1 (DMT1). Biochem J 403:59-69

52. Mackenzie B, Garrick MD (2005) Iron Imports. II. Iron uptake at the apical membrane in the intestine. Am J Physiol Gastrointest Liver Physiol 289:G981-G986

53. Andrews NC (1999) The iron transporter DMT1. Int J Biochem Cell Biol 31:991-994

54. Mims MP, Guan Y, Pospisilova D, Priwitzerova M, Indrak K, Ponka P, Divoky V, Prchal JT (2005) Identification of a human mutation of DMT1 in a patient with microcytic anemia and iron overload. Blood 105:1337-1342 
55. Iolascon A, d'Apolito M, Servedio V, Cimmino F, Piga A, Camaschella C (2006) Microcytic anemia and hepatic iron overload in a child with compound heterozygous mutations in DMT1 (SLC11A2). Blood 107:349-354

56. Salazar J, Mena N, Hunot S, Prigent A, Alvarez-Fischer D, Arredondo M, Duyckaerts C, Sazdovitch V, Zhao L, Garrick LM, Nunez MT, Garrick MD, Raisman-Vozari R, Hirch EC (2008) Divalent metal transporter 1 (DMT1) contributes to neurodegeneration in animal models of Parkinson's disease. Proc Natl Acad Sci USA 105:18578-18583

57. Tazi J, Bakkour N, Stamm S (2009) Alternative splicing and disease. Biochim Biophys Acta 1792:14-26

58. Ward AJ, Cooper TA (2010) The pathobiology of splicing. J Pathol 220:152-163

59. Stokkers PC, Huibregtse K Jr, Leegwater AC, Reitsma PH, Tytgat GN, van Deventer SJ (2000) Analysis of a positional candidate gene for inflammatory bowel disease: NRAMP2. Inflamm Bowel Dis 6:92-98

60. Keller T, Ryan E, Barrett S, O'Keane C, Crowe J (2004) DMT1 genetic variability is not responsible for phenotype variability in hereditary hemochromatosis. Blood Cells Mol Dis 33:35-39
61. Thornton J, Edwards R, Mitchell P, Harrison RA, Buchan I, Kelly SP (2005) Smoking and age-related macular degeneration: a review of association. Eye 19:935-944

62. Hirvela H, Luukinen H, Laara E, Sc L, Laatikainen L (1996) Risk factors of age-related maculopathy in a population 70 years of age or older. Ophthalmology 103:871-877

63. Chaine G, Hullo A, Sahel J, Soubrane G, Espinasse-Berrod MA, Schutz D, Bourguignon C, Harpev C, Brault Y, Coste M, Moccatti D, Bourgeois H (1998) Case-control study of the risk factors for age related macular degeneration. France-DLMA Study Group. Br J Ophthalmol 82:996-1002

64. Klein R, Klein BE, Moss SE (1998) Relation of smoking to the incidence of age-related maculopathy. The Beaver Dam Eye Study. Am J Epidemiol 147:103-110

65. Klein R, Klein BE, Tomany SC, Moss SE (2002) Ten-year incidence of age-related maculopathy and smoking and drinking: the Beaver Dam Eye Study. Am J Epidemiol 156:589-598

66. Pons M, Marin-Castano ME (2011) Nicotine increases the VEGF/ PEDF ratio in retinal pigment epithelium: a possible mechanism for $\mathrm{CNV}$ in passive smokers with AMD. Invest Ophthalmol Vis Sci 52:3842-3853 